\title{
PHYSICAL THERAPY AND SWIMMING INFLUENCE ON FEMALE TYPE OF ADIPOSE DEPOSITION AND CELLULITE
}

\author{
Ivan Maznev, Nikolay Izov, Milena Nikolova, \\ Antoaneta Dimitrova, Kristin Grigorova-Petrova
}

National Sports Academy "Vassil Levski”"

\begin{abstract}
Cellulite is a very common problem with women of all ages, and many of them try to solve it using various methods.

To evaluate the effect of swimming and physiotherapy on subcutaneous fat in overweight women with female type of adipose deposition. The research was done among 38 women aged between 22 and 48 years, with gynoid accumulation of fat and cellulite II, III-A and III-B classes. For one month, a complex of fifteen procedures was applied every other day. The procedures included a combination of the following methods: free style intermittent swimming for 20 min in a pool, a vacuum massage - 30 min, a lymphatic press massage - $20 \mathrm{~min}$, a manual massage with anti-cellulite creams - 20 min. The combination of exercises for the muscles of the abdominal wall, hip muscles and thighs had to be performed at home daily. Five circumferences and ten skin folds were measured before and after the treatment. We found out that a total of ten skin folds was an integral indicator of the nutritional obesity degree and level of subcutaneous fat.

At the end of the study, subcutaneous fat was reduced from $222.4 \mathrm{~mm}$ to $209.9 \mathrm{~mm}$ (10.34\%). The reduction of the skin folds, typical for gynoid type deposition of fat and cellulites, was the most pronounced in the following zones: a fold over anterior superior iliac spine, a fold over the patella, a fold in the popliteal fossa and a fold on the medial side of the cruris.

The results of the complex therapeutic approach revealed a reduction in the examined indicators within the first month. It is suitable to apply swimming and physiotherapy in the comprehensive treatment of cellulite with women who have female type of adipose deposition.
\end{abstract}

Keywords: cellulite, female type of fat deposition, swimming, massage techniques 


\section{INTRODUCTION}

According to medical classification, obesity is divided into two main types androgenic and gynoid. The androgenic obesity is most common with men, and it is characterized by accumulation of fat in the upper part of the body - abdomen, breasts, dewlap and hands. The gynoid type of obesity is typical with women. It is accompanied by adipocytes and fat cells which primarily compose adipose tissue, increasing in size in the hypodermis of the thighs, hips, and abdomen, where triglycerides are stored in large quantities. This leads to increasing fat stores and body circumferences in the relevant areas. Subcutaneous fat in those areas can be removed with much more difficulty when one tries to lose weight. This explains the weak effect of hypocaloric diets. Some studies show that women devote more attention to those parts of their bodies, and they often want them to be corrected with aesthetic purpose, without having an established disease and any pathological abnormality (Greenway et al., 1995).

For that reason, many authors pay particular attention to local treatment and equipment-assisted influence in these zones. In the beginning, gynoid fat distribution, and cellulite were perceived only as cosmetic defects. However, they develop progressively and influence fat metabolism, connective tissue structure, microcirculation, antioxidant activity, and other important functions in the affected body areas. That is why, during the first month of treatment, our methodology consists of procedures that induce maximum drainage of the affected areas (Topuzov, 2000; Goranova, 2001; Goranova et al., 2001; Gavriel et al., 2010).

\section{METHODS AND}

\section{METHODOLOGY}

This study was conducted at Skin Systems Medical Center in Sofia. The research was conducted among 38 women aged between 22 and 48 years, with gynoid accumulation of fat and cellulite II, III-A and III-B classes. Fifteen procedures were applied every other day within a month. The procedures included a combination of the following methods: swimming for half an hour, a vacuum massage - 30 min., a lymphatic press massage - 20 min., a manual massage with anti-cellulite creams - 20 min.

One advantage swimming has over other forms of exercise is the water pressure. Water is denser than air, and it squeezes the body gently during exercising and swimming. The use of the muscles of thighs, calves and buttocks is extensive in swimming, particularly in breaststroke and improves the circulation in cellulite-prone areas. Increasing blood circulation improves skin tone and health, and toned muscles smooth the areas where cellulite still exists. Swimming helps to burn calories, but diet also plays a role in losing weight and removing cellulite. Gradual and steady weight loss gives lasting results. Interval swimming provides good mechanical stimulation and enhanced calorie burning, so it is also a great anti-cellulite exercise (Nikolova et al., 2012; Nikolova et Lyubenova, 2016)

Vacuum massage is the first of the procedures applied. During this procedure, an SPM-apparatus (suction pump massage) made by the German company Weyergans is used; it supports up to 50 mbar of negative pressure. The vacuum massage is made with different sizes of cups, depending on the size of the treated area and a cel- 
lulite type. All problematic zones including lower limbs, bottom, abdomen, waist, arms, and dewlap are treated. Hydro gel is used to slide the suction cup from the periphery to the center. The main goal of this massage is to create a negative pressure by improving the blood circulation and lymphatic circulation in the affected areas. The lymph fluid flows slowly through the lymph system, but by means of a vacuum massage, it starts to move directly to the regional lymph nodes, releasing tissue tension. The vaccum massage reduces stagnant phenomena, improves microcirculation, and evacuates the metabolic products of the metabolism in the lymph. The negative pressure also leads to withdrawal of blood from the upper dermal layers. In turn, the improved blood supply opens the additional capillary network, increases oxygen, and leads to better tissue nutrition and reduced tissue hypoxia. This procedure is painful, therefore in the beginning the pressure is lower (15-20 mbar.), the movement of the suction cup is faster, and the vacuum is not retained for a long time within one zone. The total duration of the SPM is $30 \mathrm{~min}$. distributed over various cellulite areas, depending on the degree to which they are affected.

Lymphatic press massage is applied immediately after the vacuum massage. Covers with built-in heating filaments are wraped around problem areas of the body: upper and lower extremities, abdomen, bottom, etc. In order not to burden the heart, the inflatable cuff is wraped around the abdomen and under the breasts. In addition to heating, the cuffs also inflate and deflate (resembling a blood pressure device). The effect on problem areas includes excessive sweating and activation of metabolic processes in combination with lymphatic drainage. As a result, hypodermic areas with an increased pressure due to poor drainage, are relieved. Moreover, through the lymphatic press massage, the cold and tense cellulite formations are heated and softened, enabling unnecessary fluids and metabolites to move back into the bloodstream. The lymphatic press massage lasts from 20 to 30 minutes. The time gradually increases. After the procedure, patients take a shower and then are made a manual cellulite massage (Nikolova et al., 2012; Nikolova et Lyubenova, 2016; Lyubenova, 2006).

Mannual cellulite massage is used in combination with anti-cellulite cream which enhances the drainage and strengthens blood vessels. Rubbing and squeezing massage techniques make up for $70 \%-80 \%$ of the procedure. During the manual cellulite massage, both subcutaneous tissue and deep underlying tissues of the skin are displaced and stretched and lymph drainage is gained. In order to achieve this, we apply almost all massage squeezing techniques and some stroking methods applied with more pressure and force, as in squeezing. These massage techniques affect the tissues in depth, causing local drainage of the lymph and the blood vessels, followed by their rapid filling. This leads to fast redistribution of blood and lymph fluid in the treated areas, to elimination of stagnant phenomena, and to evacuation of metabolic products. The massage techniques always follow the direction of lymphatic and venous blood flow. The following rubbing techniques are used: spiral, ,zigzag', ,impulsion', ,brush', ,filing', ,planing' and ,rake' rubbing. Through these techniques, the skin is stretched, unstuck, and comes off the underlying tissues. The rubbing massage technique supports the 
normal skin mobility, softens pathological depositions in the tissues, and significantly increases blood circulation and lymphatic circulation. Unlike the rubbing technique in the ordinary classic massage, the rubbing technique in this massage follows the direction of the venous and lymphatic flow.

The following kneading massage techniques for lower limbs are most often used: ,double-ring', ,double fingerboard' and ,rolling'. For the abdominal and bottom areas, additional techniques such as ,stratification' and ,mixing' are used. The striking techniques that are applied include: ,patting', 'choping', ,smacking', 'spanking', and ,slapping'. The duration of the manual anti-cellulite massage is 20-30 min. After its completion, the massaged areas are wrapped tightly with a thick stretch wrap for 30-40 minutes. This is done to keep the heat caused by the massage, and induce sweating in the treated areas. This, in turn, promotes better absorption of anti-cellulite balm nutrients (Goranova, 2001; Goranova et al., 2001; Gavriel et al., 2010; Nikolova et Lyubenova, 2016; Lyubenova, 2006).
The physical activity recommended to our patients includes a combination of exercises for the muscles of the abdominal wall, hip muscles, and thighs. The exercises must be performed at home daily or every other day (Nikolova, Lyubenova, 2016; Lyubenova, 2006; Stefanova et al., 2007).

Cellulite is a very common problem with women of all ages and many of them try to solve it with long-term SPA procedures (Tasheva, 2007).

\section{RESULTS}

We found out that a total of ten skin folds was an integral indicator of the nutritional obesity degree and level of subcutaneous fat. In the process of the study, subcutaneous fat was reduced from 222.4 $\mathrm{mm}$ to $209.9 \mathrm{~mm}$, i.e. with $12.5 \mathrm{~mm}$ or $10.34 \%$.

The reduction of the skin folds, typical for gynoid type deposition of fat and cellulites, was the most pronounced in the following predilection zones: a fold over anterior superior iliac spine, a fold over the patella (kneecap), a fold in the popliteal fossa (kneepit) and a fold on the medial side of the cruris.

Table 1. Changes in the mean values of skin folds and circumferences before and after treatment

\begin{tabular}{ccccc}
\hline Indicators & $\begin{array}{c}\text { Initial } \\
\text { measurement X1 }\end{array}$ & $\begin{array}{c}\text { Final } \\
\text { measurement X2 }\end{array}$ & X1 - X2 & X1 - X2 (\%) \\
\hline $\begin{array}{c}\text { The sum of 10 skin folds } \\
(\mathrm{mm})\end{array}$ & $\mathbf{2 2 2 . 4}$ & $\mathbf{2 0 9 . 9}$ & $\mathbf{1 2 . 5}$ & $\mathbf{1 0 . 3 4 \%}$ \\
$\begin{array}{c}\text { Waist circumference of } 4 \\
\text { cm above the umbilicus } \\
(\mathrm{cm})\end{array}$ & 79.32 & 77.17 & 2.15 & $\mathbf{2 . 7 \%}$ \\
$\begin{array}{c}\text { Waist circumference } \\
\text { through umbilicus }(\mathrm{cm})\end{array}$ & 86.85 & 84.59 & 2.26 & $\mathbf{2 . 6 \%}$ \\
$\begin{array}{c}\text { Waist circumference of } 4 \\
\text { cm below the umbilicus } \\
(\mathrm{cm})\end{array}$ & 95.37 & 91.63 & 3.74 & $3.93 \%$ \\
$\begin{array}{c}\text { Circumference through } \\
\text { the hips }(\mathrm{cm})\end{array}$ & 102.98 & 99.22 & $\mathbf{3 . 7 6}$ & $\mathbf{3 . 6 5 \%}$ \\
$\begin{array}{c}\text { Circumference of the up- } \\
\text { per } 1 / 3 \text { of thigh }(\mathrm{cm})\end{array}$ & 63.27 & 60.31 & $\mathbf{2 . 9 6}$ & $\mathbf{4 . 6 5 \%}$ \\
\hline
\end{tabular}


The three circumferences of the abdomen area decreased by an average of 2.72 $\mathrm{cm}$. or $3.08 \%$. The reduction in the circumference through the hips was $3.76 \mathrm{~cm}$. or $3.65 \%$. The reduction in an upper $1 / 3$ of the thighs was with $2.96 \mathrm{~cm}$. or $4.65 \%$.

\section{CONCLUSIONS}

The results of this complex approach demonstrate a decrease in body circumferences and reduction in the skin folds within the first month of combined therapy with interval swimming, exercise therapy and massage.

\section{REFERENCES}

Gavriel, P., Kraĭdzhikova, L., Stoı̌kov, S. (2010), Dvigatelna programa za reduktsiya na telesnata masa pri nadnormeno teglo i zatlŭstyavane, Sport $i$ nauka, Vol. 6, pp. 28-33.

Goranova, Z. (2001), Nov metod za lokalno vŭzdeǐstvie pri obezitas i tselulit, Sport i nauka, Vol. 5, pp. 17-21.

Goranova, Z., L. Angelova, K., Krakhtova K. (2001), Aparaten masazh za lokalno vŭzdeǐstvie pri tselulit i obezitas, Kineziterapiya $i$ rekhabilitatsiya, Vol. 2, pp. 11-15.

Greenway, Fr., Bray, G., Heber, D. (1995), Topical fat reduction. Obesity
Res., Vol 3, Suppl 4.

Lyubenova, D. (2006), Kineziterapiya pri obmenni zabolyavaniya. V: Popov N. (red) Kineziterapiya $v$ sportnata praktika. Obshta metodika. NSA-pres, Sofiya, pp. 160-166.

Nikolova, M., Geshev, P., Izov, N. (2012), Evropeǐska obrazovatelna politika za profesionalna podgotovka po spetsialnostta „Adaptirana fizicheska aktivnost i prinosŭt na NSA „V.Levski”, Sport i nauka, Vol. 6

Nikolova, M., Lyubenova, D. (2016), Vliyanie na fizicheskite uprazhneniya vŭrkhu samochuvstvieto na zheni s tselulit, Sport i nauka (izvŭnreden brǒ 1), Vol. 1, pp. 177-182.

Stefanova, D., Lyubenova, D., Dimitrova, A., Grigorova, K. (2007), Vliyanie na kineziterapevtichna protsedura vŭrkhu posturalniya kontrol i podvizhnostta pri zheni v naprednala vŭzrast, Sport i nauka (prilozhenie), Vol. 1, pp. 229-238.

Tasheva, R. (2007), SPA\&wellnesssŭshtnost i prilozhenie. Meditsina $i$ sport, Vol.1, pp.16-20.

Topuzov, Iv. (2000), Tselulitŭt - etiopatogeneza i lechenie, Sport i nauka, Vol. 3, pp.13-16.

Correspondence:

Milena Nikolova

National Sports Academy "Vassil Levski", Sofia, Bulgaria E-mail: milenanikolova78@gmail.com 